\title{
SOCIO-DEMOGRAPHIC DETERMINANTS OF SMALL SCALE FARMERS' LAND TENURE SYSTEM IN KWARA STATE
}

\author{
Oluwafemi Oyedeji ${ }^{1 凶}$, Esther Awotunde ${ }^{1}$, Ezekiel Ojediran ${ }^{1}$, Segun Fakayode $^{2}$
}

${ }^{1}$ University of Ilorin, Kwara State, Nigeria

${ }^{2}$ Federal University Oye-Ekiti, Ekiti State, Nigeria

\begin{abstract}
This study examined the socio-demographic determinants of the type of land tenure system used by small farmers in Kwara State, Nigeria. A two-stage sampling technique was used to collect data from ninety six farmers for the purpose of this study. Once collected, the data was analyzed using both descriptive statistics and a multinomial regression model. The results of the analysis show that $72.92 \%$ of the respondents are married, $75 \%$ are males, $39.58 \%$ are aged above $40,52.08 \%$ own $6-10$ acres of land, and $75 \%$ acquired their land through inheritance. The result of the multinomial regression analysis shows that household size, the farmer's age, gender and marital status, number of farms, farm size, education level and land use type were the key determinants for the type of land tenure system used in the study area. The study concluded that most respondents have access to farmland either by inheritance or purchase, as determined by their age, gender, household size and level of education. This study therefore recommends that farmland leasing should be encouraged especially for abandoned inherited farmland, so as to put it into productive agricultural use.
\end{abstract}

Keywords: land tenure systems, small farmers, socio-demographic factors, multinomial regression, Kwara State

\section{INTRODUCTION}

Land tenure is an important component of social, political and economic structures. A multi-dimensional aspect, it brings into play social, technical, economic, institutional, legal and political aspects which, though often ignored, must be taken into account. Land tenure relationships may be well defined and enforceable either in a formal court of law or through customary structures in a community. Alternatively, they may be relatively poorly defined with ambiguities open to exploitation (Ojo, 2008). The concern about land tenure and its impact on land use and on management of natural resources is not a recent development in Africa, especially in Nigeria. The acquisition of vast tracts of land from developing countries by wealthier food-insecure nations and private investors became a widespread practice after 2007. The nature of these acquisitions led to a serious debate among researchers (Cotula et al., 2009; De Schutter, 2011; Von Braun and Meinzen-Dick, 2009; Zoomers, 2010). Also, the desirability of these largescale international land acquisitions remains a contentious issue. Empirical studies on large-scale land acquisitions are only now emerging: the newness of the phenomenon and the secrecy surrounding acquisition deals (Hallam and Cuffaro, 2011) make such evaluations quite difficult. Land availability for agricultural production in Nigeria involves a complexity of interacting variables such as population, land tenure system, level of technology and the stage of the country's development (Ojo and Afolabi, 2003). These variables, especially the land tenure system, put serious limitations on the

\footnotetext{
$\bowtie$ MSc Oluwafemi Oyedeji, Department of Agricultural Economics and Farm Management, University of Ilorin, PMB 1515 Ilorin, Kwara State, Nigeria, e-mail: oluwafemi_oyedeji@yahoo.com, https://orcid.org/0000-0002-6250-7873
} 
amount of land available to both small- and large-scale agricultural businesses because land is communally owned in the various communities and no single person has exclusive right over the piece of land he/she is using for agricultural purposes. The community leaders determine what crops (arable or perennial) to cultivate in a typical agrarian community. The plight of the farmer gets even worse if he/she is not an indigene of the community. Apart from being given a less fertile portion to farm, he/she must not cultivate perennial crops.

Land tenure is the relationship, whether legally or customarily defined, among people, as individuals or groups, with respect to land. Land tenure is an institution, i.e., rules invented by societies to regulate behavior. Rules of tenure define how property rights to land are to be allocated within societies. These rules define how access is granted to rights to use, control, and transfer land, as well as associated responsibilities and restraints. In simple terms, land tenure systems determine who can use what resources for how long, and under what conditions (Cotula et al., 2009). Land tenure is often categorized as:

- Private: the assignment of rights to a private party who may be an individual, a married couple, a group of people, or a corporate body such as a commercial entity or non-profit organization. For example, within a community, individual families may have exclusive rights to residential parcels, agricultural parcels and certain trees. Other members of the community can be excluded from using these resources without the consent of those who hold the rights.

- Communal: a right of commons may exist within a community where each member has a right to use independently the holdings of the community. For example, members of a community may have the right to graze cattle on a common pasture.

- Open access: specific rights are not assigned to anyone and no-one can be excluded. This typically includes marine tenure where access to the high seas is generally open to anyone; it may include rangelands, forests, etc, where there may be free access to the resources for all. An important difference between open access and communal system is that under a communal system non-members of the community are excluded from using the common areas.

- State: property rights are assigned to some authority in the public sector. For example, in some countries, forest lands may fall under the mandate of the state, whether at a central or decentralized level of government.

Land tenure in Nigeria can broadly be classified into three main types, namely: communal, individual (private) and public (state controlled). Communal land is such that is held under an arrangement that provides for joint or communal use of land. Under individual tenure, land is available to the individual owner for agricultural purpose, but may be given out to other farmers on a rental basis, especially for cultivation (Arua and Okorji, 1997). State-held (public) lands are usually made available to individuals or private investors, cooperative societies and other organizations or groups of individuals on request if approved by the state governor (Arua and Okorji, 1997; Land Use Act, 1978). The general performance of land tenure in Nigeria is affected by socio-economic, sociological, socio-demographic, cultural, traditional, religious and institutional factors (Eze et al., 2011).

Access to land for the rural poor is often based on custom. Customary rights to land in indigenous societies, for example, are usually created following their traditions and through the ways in which community leaders assign land use rights to the community members. These rights of access may have their origin in the use of the land over a long period. They are often rights developed by ancestral occupation and by the use of land by ancestral societies. In such cases, it is through the act of original clearance of the land and settlement by ancestors that rights are claimed.

People also use a wide range of strategies to gain access to land. These include:

- Purchase, often using capital accumulated while working as migrants in urban areas.

- Adverse possession or prescription (the acquisition of rights through possession for a prescribed period). In some countries, this may be the only method for small farmers to gain formal access to vacant or abandoned land and to bring it into productive use.

- Leasing, or gaining access to land by paying rent to the owner.

- Sharecropping, or gaining access to land in return for paying the owner a percentage of the production.

- Inheritance, or gaining access to land as a heir.

- Squatting illegally on land.

In addition to such individual strategies, access to land can be provided systematically through land reform interventions by national governments, often 
as a result of policies to correct historic injustices and to distribute land more equitably. Such land reforms usually occur in situations where much of the land is owned by a relatively small number of people and the land is idle or under-utilized (although it should be noted that determining whether land is under-utilized depends on the criteria selected for the assessment). In some countries, land restitution has been an important type of land reform. Other land reform interventions include land redistribution programs which aim at providing the rural poor with access to land and promoting efficiency and investment in agriculture. These programs are often, but not always, accompanied by the provision of subsidized agricultural services such as extension and credit. Though in some cases the state has provided access to idle or under-utilized public land, most often private land holdings have been the source of land for resettlement purposes.

Since land is an important natural resource for agricultural purposes (De Schutter, 2011) and the mode of land acquisition in Nigeria is classified (Ojo, 2008), the methods of acquiring land and their effect on smallscale farming become relevant. Also, considering the fact that there is little or no information on the determinants of land tenure systems in Nigeria, this study aimed to contribute in this area. Therefore, this study examined the socio-demographic determinants of the land tenure system (inherited, purchased or leased) used by small farmers in Kwara State. To achieve this objective, the study examined the socio-demographic characteristics of small farmers in the study area; the land acquisition methods prevalent in the study area; and the determinants of land tenure systems used by the farmers in the study area.

\section{MATERIALS AND METHODS}

The study was conducted in Kwara State whose capital is Ilorin. The State was created on May 27, 1967 along with 11 other states of the federation. Kwara State has a total land area of about $32,500 \mathrm{~km}^{2}$ which is about $3.5 \%$ of the country's total land area $\left(923,768 \mathrm{~km}^{2}\right)$ (KWSG, 2006). Considering the geographical location, Kwara State is situated at latitudes between $7^{\circ} 45^{\prime} \mathrm{N}$ and $9^{\circ} 30^{\prime} \mathrm{N}$ and at longitudes between $2^{\circ} 30^{\prime} \mathrm{E}$ and $6^{\circ} 25^{\prime} \mathrm{E}$; it lies midway between the Northern and Southern parts of Nigeria. Kwara State shares boundaries with Osun,
Oyo, Ondo, Kogi, Niger and Ekiti States as well as an international boundary with the Republic of Benin in the west. The estimated population of the state is about 2.37 million, out of which farmers account for about $70 \%$. The farming system in the State is characterized by low quality but surplus land, low population density and a cereal-based cropping pattern.

\section{Data source and sampling technique}

The study was carried out in Kwara State, Nigeria, in 2013. A two-stage sampling technique was used to collect data for this study using well-structured questionnaires. In the first stage, 4 Local Government Areas (LGA) namely Asa, Ilorin West, Ilorin East, and Edu were randomly selected from the 16 LGAs in the State. The second stage involves a random selection of twentyfive (25) farmers from each of the selected LGAs using the complete village household lists provided by local authorities. Thus, the questionnaires were administered to a total of one hundred (100) small farmers for the purpose of the study. However, only ninety-six (96) copies of the questionnaire retrieved from the respondents were valid for analysis while the remaining four were discarded due to incomplete information.

\section{Analytical tools and model}

Once collected, the data was analyzed using both descriptive and inferential statistics. The descriptive statistics used were frequency counts and percentages, while the inferential statistics employed the Multinomial Logit Regression Analysis. Most of the theory has been developed in econometrics under the label "discrete choice models." Hedeker (2003), McFadden (1973), Skrondal and Rabe-Hesketh (2003) and Train (2003) give an account of a multilevel version of such models, even though its applications are still quite rare. The multilevel multinomial logit model is a mixed Generalized Linear Model (McCullagh and Nelder, 1989) with linear predictors. The dependent variable in this study (land tenure system) was coded as 1, 2, and 3, respectively, if the land was inherited, purchased or leased. The independent variables include: level of education, age in years, number of farms cultivated, land use type, marital status, household size, and gender (coded 1 for male and 0 for female). The model of the study for the log-odds of each response was given in generic form as shown below: 
Assuming that the log-odds of each response follow a linear model, where $\alpha_{j}$ is a constant, $\beta j$ is a vector of regression coefficients, for $j=1,2, \ldots, j-1$ and

$$
\prod_{i j}=\frac{\log \left(\Pi_{i j}\right)}{z_{i j}}=\alpha_{j}+X_{i} \beta_{j}
$$

denotes the probability that the $i^{\text {th }}$ response falls in category $j$.

The econometric model for the study is explicitly stated as

$\Pi_{11}=\alpha_{11}+\beta_{11} x_{1}+\beta_{12} x_{2}+\beta_{13} x_{3}+\beta_{14} x_{4}+\beta_{15} x_{5}+\beta_{16} x_{6}+\beta_{17} x_{7}$

$\Pi_{21}=\alpha_{21}+\beta_{21} x_{1}+\beta_{22} x_{2}+\beta_{23} x_{3}+\beta_{24} x_{4}+\beta_{25} x_{5}+\beta_{26} x_{6}+\beta_{27} x_{7}$

$\Pi_{31}=\alpha_{31}+\beta_{31} x_{1}+\beta_{32} x_{2}+\beta_{33} x_{3}+\beta_{34} x_{4}+\beta_{35} x_{5}+\beta_{36} x_{6}+\beta_{37} x_{7}$

where:

$X_{1}=$ number of farms cultivated

$X_{2}=$ household size

$X_{3}=$ farmer's age (years)

$X_{4}=$ farmer's gender $(1=$ male, $0=$ female $)$

$X_{5}=$ farmer's marital status $(1=$ single, $2=$ married, 3 = divorced, 4 = widowed)

$X_{6}=$ farm size (acres)

$X_{7}=$ level of education $(0=$ non-formal education, $1=$ primary education, 2 = secondary education, $3=$ tertiary education)

$X_{8}=$ land use type $(1=$ arable crops, $2=$ permanent crops, 3 = livestock, $4=$ mixed cropping, $5=$ mixed farming)

The equations were estimated using the Maximum Likelihood Estimation (MLE) method (Rabe-Hesketh et al., 2004), with the inherited land tenure system (represented by the first equation of [2]) used as baseline.

\section{RESULTS AND DISCUSSION}

\section{Socio-demographic characteristics of respondents}

The results of the descriptive statistics presented in Table 1 show that majority $(72.92 \%)$ of the respondents are married, $75 \%$ are males, $46.88 \%$ have non-formal education, $39.58 \%$ are aged above 40 , and $56.25 \%$ have a household size of between 6 and 10 individuals.
Table 1. Socio-demographic characteristics of respondents

\begin{tabular}{|c|c|c|c|}
\hline Variable & Category & Frequency & $\begin{array}{c}\text { Percentage } \\
(\%)\end{array}$ \\
\hline \multirow[t]{2}{*}{ Gender } & male & 72 & 75 \\
\hline & female & 24 & 25 \\
\hline \multirow[t]{3}{*}{ Age (years) } & $21-30$ & 25 & 26.04 \\
\hline & $31-40$ & 33 & 34.38 \\
\hline & above 40 & 38 & 39.58 \\
\hline \multirow[t]{4}{*}{ Marital status } & single & 15 & 15.62 \\
\hline & married & 70 & 72.92 \\
\hline & divorced & 6 & 6.25 \\
\hline & widowed & 5 & 5.21 \\
\hline \multirow{3}{*}{$\begin{array}{l}\text { Household } \\
\text { size (No. of } \\
\text { persons) }\end{array}$} & $1-5$ (small) & 35 & 36.46 \\
\hline & 6-10 (medium) & 54 & 56.25 \\
\hline & above 10 (large) & 7 & 7.29 \\
\hline \multirow{4}{*}{$\begin{array}{l}\text { Level of } \\
\text { education }\end{array}$} & non-formal & 45 & 46.88 \\
\hline & primary education & 28 & 29.16 \\
\hline & tertiary education & 14 & 14.58 \\
\hline & other & 9 & 9.38 \\
\hline \multirow{4}{*}{$\begin{array}{l}\text { Number of } \\
\text { farms }\end{array}$} & one farm & 4 & 4.17 \\
\hline & two farms & 47 & 48.96 \\
\hline & three farms & 36 & 37.5 \\
\hline & above three farms & 9 & 9.37 \\
\hline \multirow{3}{*}{$\begin{array}{l}\text { Farm size } \\
\text { (acres) }\end{array}$} & $1-5$ & 38 & 39.58 \\
\hline & $6-10$ & 50 & 52.08 \\
\hline & above 10 & 8 & 8.33 \\
\hline \multirow{3}{*}{$\begin{array}{l}\text { Land } \\
\text { acquisition }\end{array}$} & inheritance & 72 & 75 \\
\hline & leasing & 20 & 20.83 \\
\hline & purchasing & 4 & 4.17 \\
\hline \multirow[t]{5}{*}{ Land use type } & arable crops & 48 & 50 \\
\hline & permanent crops & 8 & 8.33 \\
\hline & livestock & 1 & 1.04 \\
\hline & mixed cropping & 34 & 35.42 \\
\hline & mixed farming & 5 & 5.21 \\
\hline
\end{tabular}

Source: own elaboration based on survey data. 
As shown in Table (1), 52.08\% of the farmers have 6-10 acres of land, $75 \%$ (most) acquire their land through inheritance, $95.83 \%$ of the farmers cultivate at least two farms and $50 \%$ engage in arable crop production.

\section{Determinants of the farmers' land tenure} system

The result of the Multinomial Logit regression model based on the comparison of different land tenure systems is shown in Table 2. It presents the estimates of

Table 2. Estimates of multinomial logit parameters

\begin{tabular}{|c|c|c|c|c|}
\hline Land tenure & Coefficient & Std. Err. & Z & $\mathrm{P}>|\mathrm{Z}|$ \\
\hline \multicolumn{5}{|l|}{ Inheritance } \\
\hline Number of farms & 1.805 & 2.274 & 0.79 & 0.427 \\
\hline Household size & $0.1512^{* * *}$ & 0.022 & 6.69 & 0.000 \\
\hline Farmer's age & $0.713^{* * *}$ & 0.277 & 2.58 & 0.010 \\
\hline Farmer's gender & $-15.525^{* * *}$ & 3.040 & -5.11 & 0.000 \\
\hline Farmer's marital status & $347.965^{* * *}$ & 63.215 & 5.50 & 0.000 \\
\hline Farm size & 68.527 & 56.232 & 1.22 & 0.223 \\
\hline Level of education & $134.509^{* *}$ & 66.017 & 2.04 & 0.042 \\
\hline Land use type & $0.457^{* * *}$ & 0.060 & 7.56 & 0.000 \\
\hline \multicolumn{5}{|l|}{ Purchase } \\
\hline Number of farms & $0.579^{*}$ & 0.305 & 1.90 & 0.057 \\
\hline Household size & -0.188 & 0.354 & -0.53 & 0.595 \\
\hline Farmer's age & $-0.074^{*}$ & 0.044 & -1.66 & 0.098 \\
\hline Farmer's gender & $2.076^{* * *}$ & 0.748 & 2.78 & 0.005 \\
\hline Farmer's marital status & 0.485 & 0.374 & 1.30 & 0.194 \\
\hline Farm size & $-0.799^{* *}$ & 0.356 & -2.24 & 0.025 \\
\hline Level of education & 0.213 & 0.354 & 0.60 & 0.548 \\
\hline Land use type & $1.006^{*}$ & 0.597 & 1.69 & 0.092 \\
\hline \multicolumn{5}{|l|}{ Lease } \\
\hline Number of farms & 0.078 & 0.571 & 0.14 & 0.891 \\
\hline Household size & $-0.055^{* * *}$ & 0.800 & -4.87 & 0.000 \\
\hline Farmer's age & $-0.143^{* * *}$ & 0.104 & -2.98 & 0.000 \\
\hline Farmer's gender & 1.087 & 1.204 & 0.90 & 0.367 \\
\hline Farmer's marital status & 0.120 & 0.766 & 0.16 & 0.875 \\
\hline Farm size & -0.096 & 0.676 & -0.14 & 0.888 \\
\hline Level of education & $-0.168^{*}$ & 0.786 & -1.72 & 0.096 \\
\hline Land use type & 0.658 & 1.092 & 0.60 & 0.547 \\
\hline INSIG2V & 10.811 & 0.149 & 72.49 & 0.000 \\
\hline INSIG2U & -5.148 & 105240.80 & -0.00 & 1.000 \\
\hline SIGMA-V & 222.640 & 16.602 & 192.37 & 257.678 \\
\hline SIGMA-U & 0.076 & 4011.15 & 35065.81 & 64071.27 \\
\hline SIGMA2 & 49568.540 & 7399.489 & - & - \\
\hline LAMBDA & 0.0003424 & 4011.683 & 7862.754 & 7862.754 \\
\hline
\end{tabular}

${ }^{*},{ }^{* *},{ }^{* * *}$ indicates the coefficients are statistically significant at $1 \%, 5 \%$, and $10 \%$ levels of significance, respectively. Source: own elaboration based on survey data. 
parameters and their associated standard errors. The coefficients estimated are based on the log-odds scale of the entire analysis.

For the inherited land tenure system, the number of farms cultivated and farm size were the only factors not statistically significant. Among all the socio-demographic variables modeled, only the farmers' gender is negatively significant which implies that more females had access to inherited land for farming than their male counterparts. Thus, the household size (at $1 \%$ level of significance), the farmer's age (at $1 \%$ level of significance), gender (at $1 \%$ level of significance), marital status (at $1 \%$ level of significance), level of education (at $5 \%$ level of significance), and land use type (at $1 \%$ level of significance) were the key determinants for the use of the inherited land tenure system among the farmers in the study area.

For the farmers who purchased their farmland, the results revealed that the household size, marital status, and the level of education were not statistically significant. Meanwhile, the farmers' age and farm size had negative coefficients (which implies that land was purchased for farming purposes less frequently by young people than by older ones). Also, the farmers with a higher level of education were more involved in purchasing land for farming purposes than the less educated ones. Therefore, the number of farms (at 10\% level of significance), the farmer's age (at $10 \%$ level of significance), gender (at $1 \%$ level of significance), farm size (at $5 \%$ level of significance), and land use type (at 10\% level of significance) were the key determinants for the use of the purchased land tenure system in the study area.

As regards the lease land tenure system, the household size (at $1 \%$ level of significance), the farmer's age (at $1 \%$ level of significance), and level of education (at $10 \%$ level of significance) were the (negatively) significant factors determining the use of that system by the farmers in the study area. This implies that the lease land tenure system is likely to be common among young farmers characterized by a small household size and a low level of education.

\section{CONCLUSION AND RECOMMENDATION}

This study examined the socio-demographic factors determining the use of various land tenure systems in Kwara state, Nigeria, using a multinomial logit regression model. The results showed that the household size, the farmer's age, gender, marital status and level of education, and land use type were the key determinants for the use of the inherited land tenure system at $1 \%$ and $5 \%$ statistical levels in the study area. In turn, as regards farmers who purchased their farmland, the result of the analysis revealed that the number of farms, the farmer's age and gender, farm size, and land use type were the key determinants for the use of the purchased land tenure system at $1 \%, 5 \%$ and $10 \%$ statistical levels in the study area. Similarly, the household size, the farmer's age and education level were the statistically significant factors determining the use of the lease land tenure system at $1 \%$ and $10 \%$ levels in the study area. In general, it can be deduced from the study that the most common land tenure system in the study area is the one based on inheritance, and the key socio-demographic factors determining the type of the land tenure system used by farmers in the study area are the farmer's age, household size, level of education, gender, number of farms, and land use type.

Consequently, the Nigerian government's transformation efforts under Vision 2020 - which focuses on transforming Nigeria into one of the world's top 20 economies - will be facilitated if the country succeeds in the transformation of its land laws by ensuring optimal utilization of land (especially abandoned inherited farmlands) which is the key strategic resource for poor rural farmers. In this light, this study recommends that the government should create a favorable legal, administrative and institutional framework to ease farmland acquisition and usage which will have a multiplier effect on food production in the country.

\section{REFERENCES}

Arua, E. O., Okorji, E. C. (1997). Multidimensional Analysis of Land Tenure systems in eastern Nigeria. Rome: FAO.

Cotula, L., Vermeulen, S., Leonard, R., Keeley, J. (2009). Land grab or development opportunity? Agricultural investment and international land deals in Africa. Ethiopia, IIED, IFAD and FAO.

De Schutter, O. (2011). How not to think of Land-Grabbing: three critiques of large-scale investments in farmland. J. Peas. Stud., 38(2), 23-36.

Eze, C. C., Konkwo, S. O., Orebiyi, J. S., Kadiri, F. A. (2011). Land tenure system, Farm size, Innovation and Agricultural productivity in South-East Nigeria. Contributed paper for the Agricultural Economics Society's $85^{\text {th }}$ Annual 
Conference held at University of Warwick $18^{\text {th }}-20^{\text {th }}$ April, 2011.

Hallam, D., Cuffaro, N. (2011). "Land Grabbing” in Developing Countries: Foreign Investors, Regulations and Codes of Conduct. International Conference on Global Land Grabbing, 6-8 April, Brighton, United Kingdom.

Hedeker, D. (2003). A mixed-effects Multinomial Logistic Regression Model. StatMed., 22, 1433-1446.

KWSG (2006). Planning studies in Kwara State. Kwara State Government of Nigeria, Ministry of land and Regional resources.

Land Use Act (1978). Fed. Rep. Nigeria Offic. Gazet., 14, 65, 2-6.

McCullagh, P., Nelder, J. A. (1989). Generalized Linear Models. London: Chapman and Hall CRC.

McFadden, D. (1973). Conditional Logit Analysis of Qualitative Choice Behaviour. In: Frontiers in Econometrics (pp. 105-142). Academic Press: New York. Retrieved from: https://eml.berkeley.edu/reprints/mcfadden/zarembka.pdf
Ojo, S. O. (2008). Effect of Land Acquisition for Large Scale Farming on the Performance of Small Scale Farming in Nigeria. J. Hum. Ecol., 24(1), 35-40.

Ojo, S. O., Afolabi, J. A. (2003). Effects of Farm Distance on Productivity of Farms in Nigeria. J. Appl. Sci., 6(1), 3331-3334.

Rabe-Hesketh, S., Skrondal, A., Pickles, A. (2004). GllammManual. U.C. Berkeley Division of Biostatistics Working Paper Series.

Skrondal, A., Rabe-Hesketh, S. (2003). Multilevel Logistic Regression for Polytomous Data and Rankings. Psychometrika, 68, 267-287.

Train, K. (2003). Discrete Choice Methods with Simulation. New York: Cambridge University Press.

Von Braun, J., Meinzen-Dick, R. (2009). “Land Grabbing” by Foreign Investors in Developing Countries: Risk and Opportunities. IFPRI Policy Brief.

Zoomers, A. (2010). Globalisation and the Foreignisation of Space: Seven Processes Driving the Current Global Land Grabbing. J. Peas. Stud., 37(2), 56-78. 